\title{
CARTER VERSUS REAGAN: THE HUMAN RIGHTS RECORDS OF TWO ADMINISTRATIONS
}

\author{
Michael A. Kelley \\ (University of Central Arkansas)
}

\section{Introduction: Human Rights and American Foreign Policy}

The emergence of human rights as a public concern during the Carter administration was a recrudescence of the long tradition of moralism in American foreign policy. Confident that the republic is the pinnacle of political, social, and human development, Americans have believed since 1776 that the "United States must be a beacon of human rights to an unregenerate world" (Schlesinger, 1978: 505). Yet, while to the founding fathers America's avoidance of Europe's evils of class, hierarchy, and power politics was to be its greatest glory it is quite clear that they intended the U.S. to illuminate the path to a better world by example not by action. John Quincy Adam's famous July 4 speech explained his perception of America's mission to the world:

Wherever the standard of freedom and independence has been or shall be unfurled, there will her heart, her benedictions and her prayers be. But she goes not abroad, in search of monsters to destroy. She is the well-wisher to the freedom and independence of all. She is the champion and vindicator only of her own. She will commend the general cause by the countenance of her voice, and the benignant sympathy of her example (ibid.)

If repudiation of European pathologies was, as John Dos Passos states, "America's main excuse for being" (Spanier, 1980:5), then self-quarantine to avoid corruption generated a profound drive toward a smug, self-satisfied isolationism. Yet, Americans were not blind to the suffering by other oppressed peoples (at least beyond their shores) as evidenced by the Cass Resolution (1849) calling for America to actively condemn Austrian/Russian suppression of the 1848 Hungarian revolution (Schlesinger, 1978: 506-508). It is apparent therefore, quite early in the republic's history that a policy debate emerges over human rights in which some believe in the power of the U.S. as a role model and others in a more activist position - even if it is only rhetorical flagellation of evil-doers before the court of world opinion.

Throughout our history, then, the twin strands of exemplary and activist moralism color America's foreign policy. Clearly allied, of course, with this aspect is a second dimension of U.S. foreign policy posture namely, America's international role characterized by both isolationist and interventionist dimen- 
sions of behavior. Obviously, isolationism constrained America's ability to do more than exist as an example of a "proper" state or engage in the histrionics that so amused and infuriated Europeans (Bell, 1984: 493-94). W. Wilson's advocacy of international idealism/legalism being a classic example of an activist moralism without the capability and will to engage in shaping a better world (Dougherty and Pfaltzgraff, 1971: 7; Schlesinger, 1983: 4-5). In the wake of WWII and under the influence of the realist paradigm, however, U.S. elites rejected isolationism and embraced interventionism in a deliberate choice to become a world power. Realpolitik, demanded, as President Carter was later to say that "the state of our union depends on the state of the world (Ravenal, 1978: xxvi)," and that the U.S. needs to create an environment conducive to its needs and interests. And, while there were reverberations of the 19th century in the "prophets" (Kissenger, 1977) and the "crusaders" (Stoessinger, 1979) whose policies were propelled by a self-image shaped by victory and circumstance and secure in its virtuous superiority, it is clear that the emergence of post-1945 internationalism rested on the belief that the triumph of the American example was not ineluctable but rather necessitated active involvement in international affairs. If, as John Foster Dulles believed "Bolshevism is the product of the devil (Stoessinger, 1979: 98)," it was vital for a "philanthropic" American acting for the "good of others" (Kegley and Wittkopf, 1982: 41-45) to become the provider of the security requisite for the free world to become "a reflection of the United States" (Ambrose, 1983:14)." Moralism, as a policy, was eclipsed by security concerns and the U.S., therefore, paid little heed to the often unsavory aspects of its allies' domestic policies.

A consequence of the exemplary character of post-1945 moralism was that it was disjoint with the activist U.S. position in other issue areas, much like the Wilsonian period where a morally activist America failed to engage in behavior supportive of its professed ideals. And it is this inconsistency between policy and behavior that opens up administrations for criticism whether it is the failure of idealism or the insensitivity to human rights by a nation that portrays itself as the international guarantor of individual freedom and dignity. Arguably, part of the potency of President Carter's human rights appeal lay in the reconciliation of American policy involved in shaping the world but seemingly little concerned with the conditions of the people it was trying to protect. Carter's call, particularly his Notre Dame address, hence "touched exposed nerves around the planet" (Schlesinger, 1978: 501). The call not only led to the establishment of a State Department human rights bureau but also changed the flavor of American political debate. The frequency of appeal to "human rights" by both the left and right to justify particular policies is inescapable proof of the human rights legacy of the Carter administration.

If there has been a debate concerning the Carter administration's human rights' record, it has revolved around the actualization or implementation of the policy. Some authors have argued that the Carter era signaled the beginnings of 
human rights' policy that went beyond mere pious pronouncements about human dignity or a focus on the abuses of Communist bloc states to a more rigorous posture that at times took into account the human rights' record of a regime when determining the level of real U.S. support (Schoultz, 1981: Collins, 1981; Schlesinger, 1978; Fascell, 1978; Robertson, 1979). In fact, conservative Republicans, as noted by Bundy (1979), took Carter's human rights record to task complaining it hurt our "friends" in Iran and Nicaragua and was overly selective in targeting only "friendly" states such as Brazil, Chile, Paraguay, and Argentina (Buckley, 1980). On the other hand, authors such as Hoffman (1977-78: 19-20) criticized Carter's human rights record in that it was not much different from practices in earlier administrations. As Kegley and Wittkopf (1982: 556-7) explain, "Carter stressed example over action and rhetorical ideals over coercion" thus his "human rights record was less distinguished than its rhetoric." While Carter "associated human rights with a posture of moral concern" and advanced "mild institutional initiatives at the U.N." (Falk, 1980: 220), any strong policy mandating sanctions against regimes supported by the U.S. and poor human rights records were scuttled by geopolitical concerns or significant domestic economic interests (Larzeg, 1979; Early, 1978; Salzberg, 1981; Nanda, 1981; Tonelson, 1982-83).

While there appears to be some question whether Carter engaged in an activist moralism or not there seems to be little disagreement concerning the Reagan administration's attitude towards human rights. Reagan, perceiving the U.S. to be "infinitely virtuous" and a "divinely annoited land," is a messianic crusader like Dulles who believes the U.S. must protect the weak from the evil in the modern world (Schlesinger, 1983:5). As a result, Reagan's first term "bore an almost eerie similarity to the years 1949 to 1954, (Bell, 1984: 494)," leading scholars to conclude that Reagan permitted security issues to dominate moral imperatives and that "violations of human rights in other countries are not a significant concern of the United States (Kegley and Wittkopf, 1982: 556)." Convinced that communist totalitarianism is less susceptible, if at all, to democratic forces than right wing autocracies the Reagan administration argued, expressed in articles by former U.N. ambassador Jeane Kirkpatrick and Ernest Lefever (the early Reagan choice to head the State Department's human rights bureau), that support for third world authoritarians friendly to the U.S. will permit these states to evolve democratically toward the American examples which they could not do if subverted by Soviet sponsored revolutionaries (Tonelson, 1982-83: 56-57).

To summarize, there are two interrelated dimensions that impact on U.S. human rights policy, namely moralism and internationalism. And while it is easy to place some actors in the appropriate cells (see matrix below) the issue of where Carter and Reagan fit is of considerable interest and the focus of this paper. Obviously, the 19th century, exemplified by Adams' speech is a good example of a period where the U.S. did little more than assume a posture of moral 
superiority confident that reasons and the force of its example would be sufficient to have the world to follow its lead. Cell B is best identified with Wilson's failed idealism/legalism where moral admonishments were rendered ineffective by the unwillingness of the U.S. to actively promote those values inherent to Wilson's vision. Cell C reflects the bulk of the WWII era, including perhaps the Reagan administration, where a "philanthropic" America provides the security requisite for the "free world" to develop democratic and free-enterprise based societies free from Soviet inspired subversion. Finally, Cell D is characterized by an America actively using its leverage to intercede on the behalf of the oppressed citizenry of the world - or if not the world then within its client states. Presumably, the Carter administration is located in cell D.

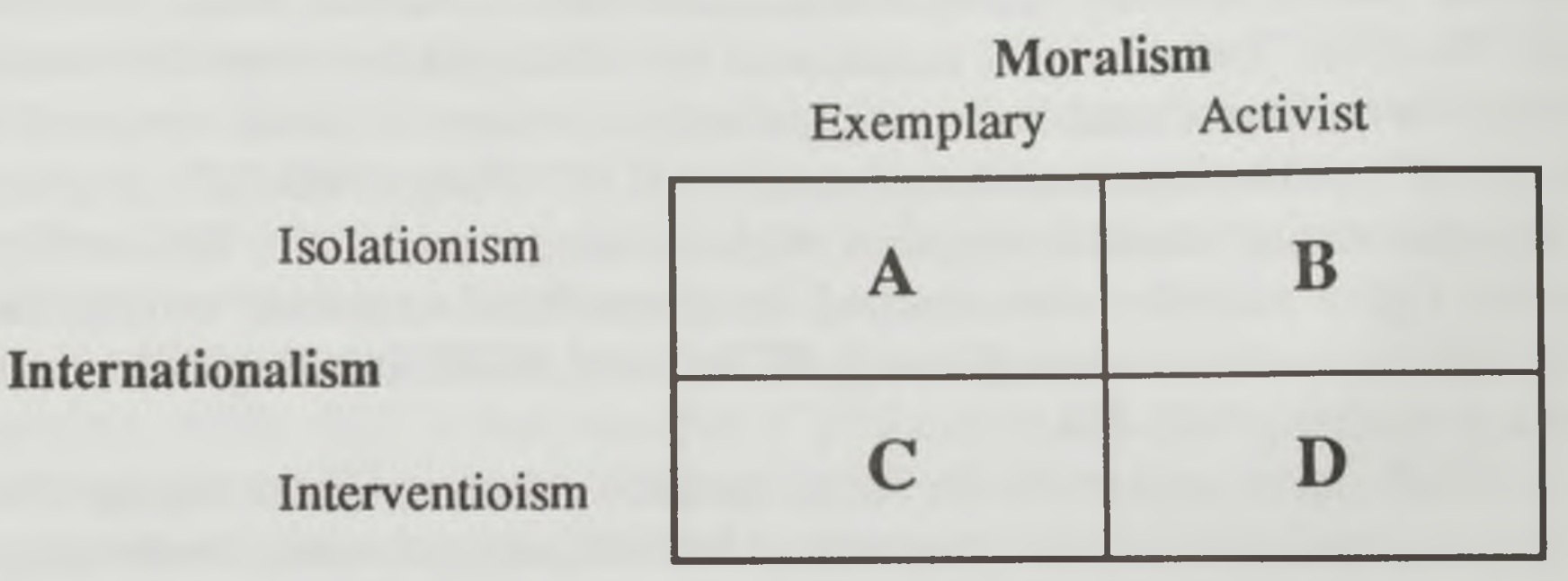

This paper is thus directed at ascertaining whether or not Carter met the policy obligations posed by his rhetoric and whether Reagan's human rights record is significantly different from his predecessor. More specifically, I am concerned with whether there are statistically significant differences in levels of U.S. support for regimes with good/poor human rights' records between the Carter and Reagan administrations and whether or not the charges that Carter punished U.S. "allies" and Reagan supports authoritarian but not totalitarian regimes are in fact correct. For, if Carter did indeed bring to foreign policy a commitment to human rights considerably different from his predecessors it must be asked whether such a policy direction continued into the Reagan administration. Certainly, Reagan talks about human rights, has not disbanded the State Department's human rights' bureau, and even proclaimed in 1984 a "human rights' day [December 10] and week. Yet, the conventional wisdom is that Reagan has turned his back on the Carter formulation and has either sought, for ideological reasons, to "emasculate" human rights' policy (Maechling, 1983: 120) or has engaged in policies that have not been effective, in terminating human rights abuses particularly by the right wing governments friendly to the U.S., (Tonelson, 1982-83). Simply put the issue is if Reagan is different than Carter how have the differences been expressed in his human rights policies. 


\section{Human Rights: Conceptualization and Operationalization}

The rich and varied literature on human rights is replete with definitional and measurement questions (Pollis and Schwab, 1979; Dominguez, 1979; Said, 1978; McCamant, 1981). Most early authors usually noted three schools of thought on human rights and identified them eventually as Western, Soviet, or Third World. Yet, in the most recent literature there has been less attention paid to the Soviet model as its primarily economic welfare and equity focus seems to have been merged into both the First World and Third World conceptualizations; while, a new formulation based on "world order" schemes that avowedly eschew the statist bias of previous views in favor of a radical reformation of existing international social political and economic systems has claimed a number of human rights adherents (Falk, 1980; Mazuri, 1978; Fields, 1978; Said, 1978). The two dominant interpretations, the Western (political and civil rights) and the Third World (social welfare) models are the focus of this paper, though the questions posed and answers provided by the emerging world orderist conceptualizations may become crucial to future understandings of human rights.

The basic and well-known concept of human rights as developed in the West, particularly the U.S., is predicated on the assumption that human beings have certain inalienable rights which may not be properly denied by government. The right to physical security and the protection of intellectual beliefs and their expression is seen quite clearly in the European Convention on Human Rights (1949) for though concerned with social rights, as Green (1978: 91) notes, the Western countries "emphasized the rights of man." On the other hand, the Third World model, equally familiar to those interested in human rights, stresses the importance of social and economic rights even at the expense of political and civil rights, thereby leading to an emphasis on standards of living as the measure of human rights most applicable to the Third World states (Boli-Bennett, 1981). As Said (1978: 2) points out, the West values "rights" while the Third World stresses "obligations", leading to a clash between the individualism of the West and the communal orientation of the Third World. In fact, it is almost an article of faith, as seen in the quote below from Andreas Fantis, Deputy General Secretary of the Progressive Party of the Working People of Cyprus (1978), separating political freedom from human rights that the Western conception of negative rights is not only inappropriate for the Third World, but that the West often violates the "human rights" of its citizens:

All humankind hold sacred the ideas of freedom, democracy, and human rights in the struggle for which millions of men and women have shed their blood or given their lives. Most constitutions of the bourgeois countries do indeed proclaim these rights, but that does not mean they are observed. How can one speak of the right to work, for example, when even officially there are 17 
million jobless in the developed capitalist countries.

While different, it is obvious that the two definitions of human rights are not necessarily mutually exclusive. In fact, as Friedlander (1981: 219) points out, economic, political, civil, and social rights' principles are enshrined in the International Bill of Human Rights. In an address at the University of Wisconsin, former Secretary of State Muskie indeed included economic needs, along with the maintenance of the integrity of the individual and civil and political rights as the definitional triad of U.S. human rights' policy (Sussman, 1980: 1-2). The Carter administration, as can be seen in the quote from Cyrus Vance below, with its greater sympathy for Third World perspectives, therefore, brought welfare issues into its formulation of human rights though the primacy of the Western approach to the subject was maintained:

The right to be free from governmental violations of the integrity of the person. Such violations include torture, cruel, inhumane or degrading treatment or punishment, and arbitrary arrest or imprisonment. And they include denial of the right to a fair trial and invasion of the home.... The right to the fulfillment of such vital needs as food, shelter, health care and education. We recognize that the fulfillment of these rights will depend, in part, on the stage of a nations economic development. But we also know that this right can be violated by a government's action or inaction-for example, through corrupt official processes which divert resources to an elite at the expense of the needy, or through indifferent to the plight of the poor.... The right to enjoy civil and political liberties - freedom of thought; or religion; of assembly; freedom of speech; freedom of press; freedom of movement both within and outside one's own country; freedom to take part in government...(Bucher, 1977: 180).

It is apparent that not only are there two distinct appreciations of human rights in the literature but that to one extent or another, both have been embraced by American foreign policy elites, at least during the Carter administration. The importance then of employing measures that are indicative of both Western and Third World conceptualization are crucial for understanding the relationship between U.S. foreign policy and the human rights record of various national regimes.

\section{Operationalization and Hypotheses}

The difficulty in accurately measuring regime performance is an excruciatingly difficult one for someone interested in cross-national and longitudinal 
studies of human rights. Scholars of the subject such as Scoble and Wiseberg (1981: 167) feel "there is today no single social accounting scheme that is adequate - both conceptually valid and quantitatively reliable" and yet, believe like Dominguez (1979: 31)" that quantitative empirical research is useful and necessary in order to make judgments about human rights." Researchers are faced with employing a series of measures that are subject to question both conceptually and methodologically. I therefore, with some trepidation, advance the following as my indicators of human rights:

A. Gastil's annual Freedom House Survey is the most ubiquitous of the comparative human rights' measures, as well as the most highly criticized. A survey that focuses explicitly on the Western conception of political and civil rights, it is, at best, considered "too narrow" (Dominguez, 1979: 32) definitionally imprecise (Scarritt, 1981: 116), and impressionistic in method (McCamant, 1981: 132); while, at worst, it is according to Scoble and Wiseberg (1981: 152163), ideologically biased, and unable to be replicated as it is methodologically arbitrary and essentially partisan in its analysis. Despite the criticisms, particularly the methodological ones, I agree with both Dominguez (1979: 32) that "the Freedom House Survey is needed for its particular kinds of political assessment" and McCamant (1981: 132), that "the data might be good enough to make wide correlations on a large sample." It is my contention that the Survey can be a useful tool if one remembers that civil rights reflecting the ability to "play a part in determining who govern or what the laws of the community are" (Gastil, 1978: 7) promote a Western and especially American understanding of human rights.

This is not an unfortunate emphasis but reflects a view of human rights with a tradition that stretches back to the Seventeenth Century incorporating the English Petition of Rights, the Habeas Corpus Act, Declaration of Independence, U.S. Constitution and Bill of Rights, French Declaration of the Rights of Man and the writings of Grotius, Locke, Montesquieu, and Jefferson (Pollis and Schwab, 1979: 2). The fact that some consider it irrelevant to the rest of the world (Larzeg, 1979; Said, 1978; Fields, 1978) does not in my mind, at least, make the Western standard useless; rather I believe that the concept, which spread from the West, is well appreciated in the Third World as indicated by Peking wall posters that proclaimed "we cannot tolerate that human rights and democracy are only slogans of the Western bourgeois (Schlesinger, 1978: 521)." Political and civil rights are after all part of the International Bill of Rights and Gastil's formulation, even if flawed, remains a useful way to operationalize human rights. ${ }^{1}$

Briefly, there are also several other reasons why Gastil's survey is adequate for gross comparisons; first, whatever the rest of the world thinks of the Western view of human rights, it is the operational code that is most employed by American decision makers and most understood by the American people. Contextually, it determines the perception of a regime and conditions the U.S. 
response, if any, to a country's human rights' record. Second, if Gastil's rankings are treated as simply expert opinion rather than scientifically precise measurements then some of the methodological points expressed by Scoble and Wiseberg (1981) are less damning. Gastil, as Blaser (1981: 268) notes, assumes an "impossible task," and I like Blaser (ibid.: 272) imagine any other judgemental scheme will suffer from similar charges of bias. Finally, treatment of Gastil's scale in a nominal fashion will in some small part reduce the need for his scale to be so methodologically pure. ${ }^{2}$

B. The Third World conception of human rights revolves, in large part, around the idea of the satisfaction of basic human needs. While, as Falk (1979: 225) notes, such welfare state criteria is not explicitly spelled out in binding legal instruments certainly such prescriptions, supported by the Universal Declaration and International Covenant on Economic, Social, and Cultural Rights, can be treated as "a matter of customary international law and of international morality-and as emergent authoritative norms."

Yet, there are criticisms of this approach; some as simple as there exist no accepted measures of which needs constitute "human rights" to more complex issues concerning the validity of the economic welfare model of rights. The emphasis on positive rights certainly rejects the traditional view which rested on the inviolable individual and replaces it with the suggestion that state action is necessary to the achievement of group and individual ends. This "modern" definition is bothersome because of the trivialization of rights under the model as interests are equated with human rights. This expanded notion of rights created inclusion and exclusion difficulties since individual interests are now equated with state obligation; where does one draw the line and, in fact, how is it possible to rationalize the conflict that occurs between interests such as freedom and extractive policy or ecology and jobs. Another interesting issue, raised by Gastil (1978), is whether or not economic welfare conceptions can be used to deny the relevance of negative rights and democratic values (Pollis and Schwab, 1979: 9$10)$, thereby, justifying the actions of regimes with histories of human rights abuses-for as the Janata Party of India points out:

History is replete with instances when those who conspire against the rights of people attempt to undermine freedom by portraying it as a luxury. They conceal the fact that fundamental freedoms are weapons the poor need to fight tyranny. Bread cannot be juxtaposed against liberty. The two are inseparable (Gastil, 1978: 6).

Yet, even Gastil sees the value of including some welfare increase, and in fact, in the 1982 Survey included a section on economic freedoms, albeit from a capitalist bias (Wright, 1982). So the question becomes what is/are the appropriate measure(s) with the most common answer being the Physical Quality of Life 
Index (PQLI) developed by the Overseas Development Council. The PQLI, however, as Scoble and Wiseberg (1981: 164-167) note has been criticized on methodological grounds and, in particular, the reports cited by Blaser (1981: 276-277) seem to be quite telling, indicating that two parts of the ODC's index, i.e., life expectancy and infant morality, (the other being literacy), are "too similar to warrant their weighting as two-thirds of a people's quality of life." Correspondingly, I will use separately literacy rates and life expectancy as measures of economic welfare.

C. The level of U.S. support will be measured by total economic and/or military aid to a regime. ${ }^{3}$ Obviously, the U.S. exercises some control over these funds and can use them to reward or sanction regimes whose policies are incongruent with American goals and values. It is assumed that the Carter administration evidenced a greater sensitivity on global scale and/or to our clients, human rights behavior when determining aid levels than the Reagan administration. This relationship should be especially pronounced when the effect of change in a country's human rights record on U.S. aid is examined. ${ }^{4}$

An analysis of variance (ANOVA) and eta (developed by the use of dummy variables) will be used to study the relationships between human rights and U.S. aid in the two administrations. ANOVA will not only allow for the determination of whether a regime's human rights' performance matters in terms of U.S. aid, but also whether the variation in foreign economic and military aid is a consequence of different policies of the Carter and Reagan administrations. Moreover, the strength of the relationship between the dependent variable, i.e., grants and credits, and the categorical variables can be determined by SPSS's ANOVA program. Eta, of course, will permit a determination of the level of association between an administration's foreign aid giving and a regime's human rights record.

More specifically, and with the above in mind, the following represent the central questions of this paper:

(1) Does the record of regimes, whatever the definition of human rights is used, matter vis a vis the giving of U.S. economic and/or military assistance.

(2) Is there a particular operational code that undergirds an American understanding of human rights that is reflected in U.S. aid policy; i.e., how do the foreign policy elites define human rights?

(3) Did the Carter administration create a coherent pattern of reward and denial of aid based on a human rights doctrine significantly different from the succeeding administration? And, was this policy directed more at "friendly" than other states? 
(4) Is the Reagan administration antithetical to the idea of human rights being used as a criteria in determining aid to foreign countries? Or does his administration employ a distinction between authoritarian and totalitarian regimes when fixing levels of U.S. aid?

\section{Results}

The statistics displayed below are indicative of an ambivalent relationship between human rights measures and an administration's foreign aid policy. Table 1 shows, for example, that in a global sample of 92 states (see Chart 2) neither the Carter nor Reagan administrations distinguished among human rights records when distributing U.S. foreign aid. It must be concluded, therefore, that for question one the answer is a resounding "no", and that there was no coherent global human rights posture advanced by either administration.

While the answer to question one is a definite "no", the answer to the issue of whether an "operational code" determining U.S. foreign policy elites' definition of human rights exists or not is a mixed one. It is apparent from the ANOVA statistics in Tables 2 and 3 and the questionable results in Table 1 between GASPOL and change in economic and military aid that the western version of human rights tends to support and define U.S. policy. Of the 8 significant Fstatistics in Table 2 and the 11 found in Table 3,5 (63\%) and $6(55 \%)$ respectively involve either a derivation of one or more of Gastil's measures of human rights. Surprisingly, however, is the strength of the economic measures of human rights in determining U.S. aid levels, especially during the Carter administration. So while it is possible to say that a western perception underlies U.S. aid it is also accurate to note that the U.S. also exhibits some concern for the idea of "economic liberty" found in the third world definition of human rights.

Of course, the issue of whether or not Carter used American aid to reward or punish recipients predicated, in part, on their human rights records is still open to question. In the global sample (Table 1) there is no correlation between the Carter administration's aid and a regime's human rights history. However, Table 3 supports the idea that Carter did consider human rights records when giving assistance, especially military aid, to "friendly states." This indicates that Carter did indeed treat nations with which the U.S. had both economic and military ties differently than the rest of the world. In sum, while there is an association between some human rights measures and U.S. aid to "friendly states" it is clear that Carter did not have a global policy and as such was not any different than the succeeding administration. In fact, no matter which definition is used the interaction effects of President and human rights (Table 2) are never significant.

Finally, taking Tables 2 and 4 together it is possible to say that not only has the Reagan administration no coherent global human rights policy, and/or that it does not even utilize the distinction between authoritarian and totalitarian regimes advanced by its apologists when granting either economic or military 
aid. The ANOVA and eta2 statistics demonstrate no significant relationship between regime character and U.S. aid in either the total or "friendly" state samples. Moreover, given the almost uniformly lower F and eta2 statistics in the "friendly" sample it is possible to observe that the Reagan administration seems less concerned with its allies' human rights records than other nations.

\section{Conclusion}

If anything startling emerges from this study it is the association between human rights records and U.S. aid to "friendly states" particularly military assistance, in the Carter administration. This finding should confound those who believe Carter's record was nothing more than rhetorical flourishes with little if any intervention to promote human rights among recipients of U.S. aid. The fact, Carter focused more on those countries with which the U.S. had some leverage rather than a global policy reflects both a hard-headed realism and an awareness of the limited capacity, given the availability of foreign aid funding, to engage in a worldwide human rights crusade. The concentration on "friendly states," 14 of 16 being either authoritarian or totalitarian based on Gastil's measures, also lends credence to those who argued that Carter was more concerned with the "sins" of our friends and less with the transgressions of other states (Abrams, 1983-84: 174). Whether this was an unfortunate fact or realistic politics, it is obvious that the congruence between Carter's moral activism and intervention on behalf of human rights creates a powerful legacy that evidently has not been fully appreciated by the scholarly community.

On the other hand, the Reagan administration apparently pays little attention in determining aid levels to the human rights records of U.S. aid recipients. In fact, as Table 4 indicates considerations other than human rights seem to guide U.S. aid to friendly states even though the Reagan administration has not been reticent in discussing the role of human rights. (Ibid.: 173-174) Given the lack of criticism of "friendly states", (though the role played by Reagan in hastening Marcos' departure is interesting) and the failure to reward or punish on the basis of human rights violations it seems Reagan, like Bell (1984:494) and Kegley and Wittkopf (1982: 552-555) point out, is cut from the 1950's mold, in that, strategic considerations protect "friendly" transgressions, while, a drumbeat of criticism (deserved, of course) is directed at the Soviets and their clients' human rights practices. As a result, the Reagan administration falls into Cell $\mathrm{C}$ of the matrix employed earlier to explain the development American human rights policies.

Finally, a couple of other observations can be made concerning human rights and U.S. aid:

(A) It is apparent that military assistance seems to be the dependentvariable most susceptible to manipulation by the U.S. to indicate approval/ 
disapproval of a regimes human rights record. This supports (Shoultz; 1981) who found during the Carter era military aid was correlated with Latin American states' human rights records.

(B) There seems to be patterns in U.S. aid with these long term commitments detracting from the utility of changes in economic and military aid as dependent variables. Certainly, one of the major disappointments, except in Table 1, was the lack of power of changes in aid in relation to the human rights records of states. Apparently, short term fluctuations in aid are less a function of human rights concerns than fundamental aid levels.

(C) The emphasis on a global sample may be disguising real differences in regions. For example, the pattern of U.S. aid to Central America is certainly perceived to be substantially different between Carter and Reagan eras. Probably, a breakdown of U.S.aid of both a military and economic nature should be done at the regional level in order to uncover possible regional differences among the administration's grant and credit policies.

(D) I am persuaded by the literature that grand ideas, while they may not be expressed consistently in policy, have a value in and of themselves. Carter brought human rights into the public domain, created an institutional interest group in the State Department with a vested interest in promoting human rights, and essentially performed a consciousness raising function by reminding America of the ethical imperatives of its policies. The fact, that Carter was able to implement his human rights vision, albeit in a limited number of states to which U.S. support was important, is in many ways a bonus for human rights will continue to be part of at least the rhetoric of American foreign policy.

Table 1

Correlations Between U.S. Aid and Measures of Human Rights by Administration $\left(R^{2}\right)$ N of Cases $=92$

TOTAL 'GASPOL 'GASCIV 2 SLIT 2 SLIFE $2 \mathrm{SPCI}$ 'SCIV 'SPOL 4CPOLS 4CCIVS 4CPCIS ECONOMIC AID Carter Reagan .088 .031

$\begin{array}{lll}.112 & .028 & .023 \\ .036 & .023 & .028\end{array}$

$\begin{array}{lll}.003 & .029 & .035\end{array}$

.016 .010

TOTAL.

MitTary AID

Carter

Reagan 


\section{Carter Versus Reagan: Civil Rights Records}

\section{Table 2}

Significance Levels of ANOVA Between Human Rights Measures, Administrations, and U.S. Foreign Aid ( $\mathrm{N}=92)$

Admin/ Admin/ Admin/ Admin/ Admin/ Admin/ Admin/ Admin/ Admin/ Admin/ GASPOL CASCIV SLIT SLIFE SPCI SCIV SPOL CPOLS CCIVS CPCIS

Total EConomic AID

Admin

Ind. Var.

$\begin{array}{llllllllll}.969 & .679 & .870 & .850 & .756 & .702 & .959 & .619 & .591 & .544\end{array}$

2 way interaction

$\begin{array}{llllllllll}.050 & .149 & .122 & .120 & .752 & .101 & .076 & .977 & .665 & .701\end{array}$

(Carter/Reagan)

\section{TOTAL MIITARY AID}

Admin.

Ind. Var.

$\begin{array}{llllllllll}.654 & .554 & .626 & .529 & .558 & .445 & .652 & .274 & .289 & .297\end{array}$

2 way interaction

(Carter/Reagan)

\section{Table 3}

Canter's Record on "Friendly States"* N=16

TOTAL

GASPOL GASCIV SLIT SLIFE SPCI SCIV SPOL CPOLS CCIVS CPCIS

ECONOMIC AID

$\begin{array}{lllllllllll}\text { ANOVA F } & .117 & .011 & .239 & .044 & .000 & .000 & .000 & .721 & .168 & .267 \\ \text { ETA }^{2} & .376 & .668 & .197 & .383 & .946 & .962 & .934 & .049 & .240 & .184\end{array}$

TOTAL

Mintary AID

ANOVA F

ETA $^{2}$

*Friendly in this case are states (16 out of a 93 global sample) that received at least $\$ 1$ million in both econanic and military aid.

\section{Table 4}

Reagan's Record

Totalitarian v. Authoritarian for "Friendly States $(\mathrm{N}=14)$ " and Total Sample $(\mathrm{N}=92)$

\begin{tabular}{llll} 
& & ANOVA F & ETA $^{2}$ \\
TotAL & & .700 & .006 \\
ECONOMIC AID & Friendly & .822 & .001 \\
& Total & & \\
\hline TOTAL & & .601 & .011 \\
MIITARY AID & $\begin{array}{l}\text { Friendly } \\
\text { Total }\end{array}$ & .527 & .005 \\
\hline
\end{tabular}

Totalitarien is when SPOL $=3$ and SCIV $=3$, SPOL $=3$, and SCIV=2, and SPOL $=2$ and SCIV =3 Authoriturian is when SPOL $=2$ and $\mathrm{SCIV}=2$. 


\section{Endnotes}

${ }^{1}$ The operationalization of Gastil's political and civil freedoms concepts is based on the division of his 7 categories of states into Free, Partly Free, and Not Free. The resulting three classes of states are used in the ANOVA rather than the 7 categories for the reasons of parsimony; the fact that the greater imprecision negates some of the methodological criticisms of Gastin's 7-unit scale; and the problem of making sure there were sufficiend cell N's. The Data was taken from Gastil's 1975, 1978, and 1982 Surveys, and all states were included except members of NATO and European neutrals with no record of having significant and sustained human rights.

${ }^{2}$ All states ranked on the basis of literacy rates, life expectancy, per capita income (PCI), and change in PCI with the bottom 25\% given a low, the Mid 50\% a medium, and the top 25\% a high rank in the various categories. The data was taken from several sources including the Arms Control and Disarmament Agency, U.S. Statistical Abstracts and World Military and Social Expenditures.

${ }^{3}$ Dependent variable data was gleaned from the Department of State's U.S. Overseas Loans and Grants and Assistance Annuals (1976, 1978, and 1983).

${ }^{4}$ States that had a change in their political and/or civil freedom scores, according to Gastil's 7 categories, were given a positive or negative, or no change rating according to their scores 1975-1978 and 1978-1982.

\section{References}

Abrams, Elliott, 1983-84 "Letters." Foreign Policy, Winter, 1983-84, No. 53.

Ambrose, Stephen, 1983. "Globalism in American Foreign Policy" in C.W. Kegley, Jr., and E.R. Whittkoph's Perspectives on American Foreign Policy. New York: St. Martin's.

Bell, Coral, 1984. "From Carter to Reagan" in Foreign Affairs' America and the World. New York: Pergamon Press.

Blaser, Art, 1981. "Assessing Human Rights: The NGO Contribution," in Ved P. Nanda, et al.'s, Global Human Rights (Colorado, Westview).

Boli-Bennett, John, 1981. "Human Rights on State Expansion," in Ved P. Nanda, et al.'s, Global Human Rights (Colorado, Westview).

Buckley, William F., 1980. "Human Rights and Foreign Policy: A Proposal." Foreign Affairs. Spring, 1980, Vol. 58, No. 4.

Bull, Hedley, "Consistancy Under Pressure," Foreign Affairs, Vol. 57, No. 3, 1978.

Buncher, Judith F., 1977. Human Rights and American Diplomacy, 1975-77 (New York: Freedom House).

Bundy, William P., 1979. "Foreign Policy in the 1980 Campaign." Foreign Affairs, Fall, 1979, Vol. 58, No. 1.

Collins, Stephen, 1981. "The Carter Administration - An Appraisal" Global Human Rights: Public Policies, Comparative Measures and NGO Strategies (Colorado: Westview).

Dominguez, Jorge I, 1979. "Assessing Human Rights Conditions," in J. Dominguez, et al.'s, Enhancing Global Human Rights (New York: McGraw-Hill).

Dougherty, James A. and Robert L. Pfaltzgraff, Jr., 1971. Consending Theories of 
International Relations. New York: J.B. Lippincott.

Early, Tracy. "A Crusade Quickly Cancelled," Worldview, July-August, 1978.

Falk, Richard, 1980. Human Rights and State Sovereignty. (New York: Holmes \& Meiriz).

Falk, Richard, 1979. "Responding to Severe Violations," in I.I. Dominquez, et al.'s, Enhancing Global Human Rights (New York: McGraw-Hill).

Fantis, Andreas, 1978. "The Human Rights Issue Once Again," World Marxist Review, August.

Fascell, Dante, “Did Human Rights Survive Belgrade," Foreign Policy, No. 31, Summer, 1978.

Fields, A. Blenden, 1978. "Human Rights and World Resources," in A.A. Said's Human Rights and World Order (New York: Praeger).

Friedlander, Robert A. "Human Rights Theory and NGO Practice," in Ved P. Nanda, et al.'s, Global Human Rights (Colorado: Westview).

Gastil, Raymond, 1982. "The Comparative Study of Freedom," in Freedom at Issue No. 64, January-February.

Gastil, Raymond, 1978. Freedom in the World. (Boston: G.K. Hall).

Gastil, Raymond, 1975. "The Comparative Study of Freedom," in Freedom at Issue No. 29, January-February.

Green, James F., 1978. "NGO's," in A.A. Said's Human Rights and World Order (New York: Praeger).

Hoffmann, Stanley. Winter 1977-78. "The Hell of Good Intentions," ForeignPolicy, No. 29.

Hoffman, Stanley, "The Perils of Incoherence," Foreign Affairs, Vol. 57, No. 3, 1978.

Humana, Charles, 1984. World Human Rights Guide. (New York: Pica Press).

Kegley, Charles W., Jr. and Eugene R. Wittkoph, 1982. American Foreign Policy Pattern and Process. New York: St. Martin's.

Kissinger, Henry A., 1977. American Foreign Policy. New York: W.W. Norton \& Co. Larzeg, Marnia, 1979. "Human Rights, States and Ideology," in A. Pollis and P. Schwab's Human Rights: Cultural and Ideological Perspectives (New York: Praeger).

Maechling, Charles, "Human Rights Dehumanized," Foreign Policy, No. 52, Fall, 1983. Mazuri, Ali, 1978. Idi Amim versus Jimmy Carter," Trialogue, Vol. 19, Fall.

McCamant, John F., 1981. "A Critique of Present Measures of Human Rights Development" and an alternative in Ved. P. Nanda, et al.'s, Global Human Rights (Colorado: Westview).

Nanda, Ved, 1981. "Human Rights and U.S. Foreign Policy Under Carter," in V.P. Nanda, J.P. Scarritt, and G.W. Shepeherd's Global Human Rights:Public Policy, Comparative Measures, and NGO Strategies (Colorado: Westview).

Pollis, Adamantia and Peter Schwab, 1979. Human Rights: Cultural and Ideological Perspectives (New York: Praeger).

Ravenal, Earl C., 1978. Never Again. Philadelphia: Temple University's Press.

Robertson, A.H., 1979. "Human Rights: A Global Assessment," in D.P. Kommers and G.D. Loescher's, Human Rights and American Foreign Policy (Notre Dame: Notre Dame Press.)

Said, Abdul A., 1978. "Pursuing Human Dignity," in A.A. Said's Human Rights and World Order (New York: Praeger). 
Salzberg, John, 1981. "The Carter Administration an Appraisal," in V.P. Nanda, J.P. Scarritt, and G.W. Shepeherd's Global Human Rights: Public Policies, Comparative Measures, and NGO Strategies (Colorado: Westview).

Scarritt, James R., 1981. "Definitions, Dimensions, Data, and Designs," in Ved. P. Nanda, et al.'s, Global Human Rights (Colorado: Westview).

Schlesinger, Arthur, "Human Rights and the American Tradition," Foreign Affairs, Vol. 57, No. 3, 1978.

Schlesinger, Arthur, Jr., 1983. "Foreign Policy and the American Character," Foreign Affairs, Fall, 1983, Vol. 62, No. 1.

Schoultz, Cars, 1981. "U.S. Policy Toward Human Rights in Latin America," in V.P. Nanda, J.P. Scarritt, and G.W. Shepeherd's Global Human Rights:Public Policies, Comparative Measures, and NGO Strategies (Colorado: Westview).

Scoble, Henry M. and L.S. Wiseberg, 1981. "Problems of Comparative Research in Ved. P. Nanda, et al. 's, Global Human Rights (Colorado: Westview).

Sivard, Ruth L. World Military and Social Expenditures, 1981 and 1982 (Leesburg: World Priorities).

Spanier, John, 1980. American Foreign Policy Since 1945. New York: Halt, Rinhart and Winston.

Stoessinger, John G., 1985. Crusaders and Pragmatists. New York: W.W. Norton and Co.

Sussman, Colleen, 1980. Secretary Muskie, The Foreign Policy of Human Rights. Current Policy, No. 241, (Washington, D.C.: U.S. Department of State).

Tonelson, Alan, "Human Rights: The Bias We Need,: Foreign Policy, Winter, 1982-83. U.S. Department of State, U.S. Overseas Loans and Grants and Assistance Annual (1976, 1978, 1983).

United States Arms Control and Disarmanent Agency, World Military Expenditure Arms Transfers 1982 (Washington: ACDA).

United States Statistical Abstracts 1975-84, (Washington: Census Bureau).

World Bank World Development Report 1979, 1981, 1983, 1984 (New York: Oxford). Wright, Lindsay, 1982. "A Survey of Economic Freedom," in Freedom at Issue, No. 29, January-February. 